\title{
Effect of Drying Methods and Extraction Solvents on Phenolic Antioxidants and Antioxidant Activity of Scurrula ferruginea (Jack) Danser (Loranthaceae) Leaf Extracts
}

(Kesan Kaedah Pengeringan dan Pelarut Pengekstrakan Antioksidan Fenolik dan Aktiviti Antioksidan Ekstrak Daun Scurrula ferruginea (Jack) Danser (Loranthaceae))

\author{
VAnielie Terrence Justine, Muskhazli Mustafa, Sulaiman S. KAnKara \& RuSEA GO*
}

\begin{abstract}
Scurrula ferruginea is a type of mistletoe from the Loranthaceae family found in Southeast Asia and distributed in tropical regions, is known to have healing effects for many disorders. Preservation of the bioactive metabolites is dependent on the sample preparation and drying methods as well as extraction solvents used. Thus, the present study was carried out to investigate the effect of different drying methods and extraction solvents on the total phenolic and the antioxidant activities of $\mathrm{S}$. ferruginea leaves. The leaves of $\mathrm{S}$. ferruginea were air and oven $\left(60^{\circ} \mathrm{C}\right)$ dried and extracted with aqueous, organic and aqueous-organic solvents. The total phenolic content (TPC) and total flavonoid content (TFC) were used to gauge the phenolic antioxidants extracted, while the antioxidant activity was evaluated by measuring the scavenging effect on 2,2-diphenyl-1-picrylhydrazyl (DPPH) radical and via the ferric reducing antioxidant power (FRAP) assay. The optimum conditions obtained were oven drying, $80 \%$ acetone with values of $3.47 \mathrm{mg} / 10 \mathrm{~g} \mathrm{DW}$ (extract yield), 171.29

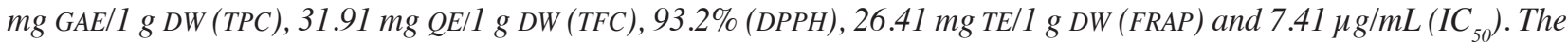
present findings suggested that sample preparation variability using different drying methods and solvents for extraction play a crucial role in enhancing the efficiency of extraction and efficacy of the antioxidant compounds in $\mathrm{S}$. ferruginea leaf extracts.
\end{abstract}

Keywords: Bioactive metabolite; mistletoe; Southeast Asia

\section{ABSTRAK}

Scurrula ferruginea adalah sejenis pokok dedalu daripada famili Loranthaceae yang boleh ditemui di Asia Tenggara dan tersebar meluas di kawasan tropika dan telah diketahui mempunyai kesan penyembuhan terhadap pelbagai penyakit. Pengekalan metabolit bioaktif bergantung kepada kaedah penyediaan sampel dan kaedah pengeringan serta pelarut pengekstrakan yang digunakan. Oleh itu, penyelidikan ini dijalankan untuk mengkaji kesan kaedah pengeringan dan pelarut pengekstrakan terhadap kandungan fenolik dan aktiviti antioksida daun S. ferruginea. Daun S. ferruginea dikeringkan melalui pengeringan udara dan ketuhar $\left(60^{\circ} \mathrm{C}\right)$ dan diekstrak menggunakan air, pelarut organik dan organik berair. Jumlah kandungan fenolik (TPC) dan jumlah kandungan flavonoid (TFC) telah digunakan untuk memantau antioksidan fenolik yang diekstrak, manakala aktiviti antioksidan dinilai dengan mengukur kesan pada radikal 2,2-difenil-1-pikrilhidrazil (DPPH) dan asai Kuasa Antioksidan Penurunan Ferik (FMKA). Hasil optimum diperoleh melalui pengeringan ketuhar dan penggunaan pelarut $80 \%$ aseton iaitu $3.47 \mathrm{mg} / 10 \mathrm{~g} \mathrm{DW}$ (hasil ekstrak), $171.29 \mathrm{mg} \mathrm{GAE} / 1 \mathrm{~g} \mathrm{DW}$ (JFK), $31.91 \mathrm{mg} Q \mathrm{QE} / 1 \mathrm{~g}$ DW(JKF), 93.2\% (DPPH), $26.41 \mathrm{mg}$ TE/1 g DW (FMKA) dan $7.41 \mu \mathrm{g} / \mathrm{mL}\left(\mathrm{IC}_{50}\right)$. Keputusan kajian ini mencadangkan bahawa variasi kaedah penyediaan sampel daripada segi kaedah pengeringan dan pelarut pengekstrakan yang digunakan memainkan peranan penting dalam meningkatkan kecekapan pengekstrakan dan keberkesanan sebatian antioksidan dalam ekstrak daun S. ferruginea.

Kata kunci: Asia Tenggara; dedalu; metabolit bioaktif

\section{INTRODUCTION}

A universal drying method and solvent extraction protocol to obtain natural antioxidants and phenolic compounds from plants are both important due to the diverse composition of phenolic compounds, chemical structures, and properties in plants (de Freitas Araújo \& Bauab 2012). Drying is a vital method for the preservation of plant phytochemicals; it allows rapid protection against deterioration, microbial attack, and enzymatic processes that occur (Rodriguez et al. 2016). Traditionally, air drying is the preferred method of drying, while oven drying is considered the latest method. The drying process is important in determining the quality of the final product that contributes to high efficiency and efficacy of medicinal plants. A good choice of drying method may lead to an increase in the phenolic compounds extracted 
from the plants, thereby accounting for better antioxidant properties.

Plant phytochemicals consist of a complex structure of phenolic compounds with varying polarity (Khoddami et al. 2013). The solvent extraction method has been used for the extraction of miscellaneous phenolic compounds from plant materials. The aqueous solvent, which is a polar solvent, is commonly used in ethnobotany practices. However, the use of different types of organic solvents and their combination with water is gaining wide acceptance as a result of the influence on the yield of phenolic antioxidants (Garcia-salas et al. 2010). The choice of solvents with varying polarity is recommended in order to select the optimum activity prior to screening of the antioxidant activity of the compounds.

Medicinal plants contain natural compounds in the form of secondary metabolites that are important to man due to their potential benefits to human health (Sultana et al. 2009). Bioactive metabolites consist of phenolic compounds, nitrogen compounds, vitamins and terpenoids that are rich in antioxidants. These active ingredients play significant roles in inhibiting pathogenic processes, such as in cancer, cardiovascular diseases, inflammation, neurodegenerative diseases and accelerated aging, and also in enhancing immune functions (Kankara et al. 2014; Mahmoudi et al. 2015). Various anti-infective studies of phenolic compounds and antioxidants have been carried out to assess their antibacterial, antifungal, and antiviral activities (Onivogui et al. 2015; Puneetha et al. 2014).

Death resulting from cardiovascular diseases caused by Reactive Oxygen Species (ROS) are twice the number of deaths resulting from cancer (Townsend et al. 2015). Collectively, it is the number one killer disease in Malaysia (WHO 2015). Cardiovascular diseases are derived from oxidative stress. Oxidative stress is an imbalance between the natural antioxidant defense mechanism in the human body and reactive oxygen species (Maruyama \& Iso 2014). Reactive Oxygen Species (ROS) cause Low-Density Lipoprotein (LDL) oxidase and formation of plaques in the heart arteries which results in accumulated clots that occur via thrombosis thus leading to blockage of blood flow and death. Antioxidants act as a 'silver bullet' that can delay and avert the oxidation reaction of substrate molecules by the reactive oxygen species thus neutralizing the effects (Ismail et al. 2010). Natural antioxidants from medicinal plants are known to have additional beneficial health effects, such as the potential to prevent diseases like cancer and heart diseases, compared to the synthetic ones (Alimpić et al. 2014).

The Malaysian mistletoe, Scurrula ferruginea (Jack) Danser is a hemi-parasitic plant from the Loranthaceae family that derives nutrients from host tissues through a complex endophytic system (Salle 1978). It is known as 'dedalu api merah' in Malay and is widely used in Chinese traditional and Southeast Asian folk medicine. It is mainly distributed in China, Cambodia, Indonesia, Laos, Malaysia, Myanmar, the Philippines, Thailand and Vietnam (Qiu \& Gilbert 2003). Only two species of Scurrula are found in Malaysia i.e. S. ferruginea and S. parasitica (Turner
1995). The leaves are used traditionally for the treatment of shingles, malaria, wounds, snake-bites, hypertension and gastrointestinal conditions; and also as protective medicine after childbirth, and to ease urination pain (Burkill 1966; Lemmens \& Bunyapraphatsara 2003; Mat-Salleh \& Latiff 2002; Werner 2002). To the best of our knowledge from the available literature, there has been no study on the preservation of the phenolic compounds and antioxidant activities of $S$. ferruginea based on the drying methods and extraction solvents used. Plant sample preparation method must be carefully chosen to enhance the efficiency and efficacy of the bioactive molecules in plant extracts. Hence, this study was undertaken to determine the effect of different drying methods and extraction solvents on the phenolic antioxidants and antioxidant activity of $S$. ferruginea (Jack) Danser (Loranthaceae) leaf extracts.

\section{MATERIALS AND METHODS}

\section{PREPARATION OF PLANT MATERIAL}

The leaves of Scurrula ferruginea were collected at the full flowering stage. The plant was taxonomically authenticated by Prof. Dr. Rusea Go of the Department of Biology, UPM, Malaysia and a voucher specimen (RG4664) was deposited at the Herbarium of the same Department. The leaf samples were dried (air drying and oven drying). For air drying, the leaves were spread evenly on a plank board at $27 \pm 1^{\circ} \mathrm{C}$ until fully dried for 3 to 4 weeks. For oven drying, the leaves were completely dried in an oven at $60^{\circ} \mathrm{C}$ for $24 \mathrm{~h}$. The dried leaves were ground using a mill. The powdered samples obtained were packaged in nylon linear low-density polyethylene pouches and stored in the dark at ambient temperature.

\section{CRUDE EXTRACT PREPARATION}

The method described by Obeidat et al . (2012) was adopted with slight modification. Ten grams of powdered materials were soaked in $80 \%$ methanol, $80 \%$ acetone, benzene and deionized water solvents $(1: 10 \mathrm{w} / \mathrm{v})$, respectively, and extracted for $24 \mathrm{~h}$ at $28 \pm 2^{\circ} \mathrm{C}$ with vigorous shaking using an orbital shaker at $200 \mathrm{rpm}$. The samples were then filtered through Whatman No. 1 filter paper (Whatman International Ltd, England) before the filtered aqueous extracts were lyophilized. The extracts were evaporated using a rotary evaporator at $40 \pm 1^{\circ} \mathrm{C}$. The dried crude extracts were weighed and a stock solution $(100 \mathrm{mg} / \mathrm{mL})$ was prepared by diluting it according to the solvent before keeping at $-20^{\circ} \mathrm{C}$ in a freezer. The yield percentage of the extracts were each determined using the following formula:

Extract yield $(\mathrm{mg} / \mathrm{g} \mathrm{DW})=[$ Extract $(\mathrm{mg}) /$ dried weight $(\mathrm{g})]$

\section{DETERMINATION OF TOTAL PHENOLIC CONTENT (TPC)}

The Total Phenolic Content (TPC) was determined using Folin-Ciocalteu (FC) method as described by Thoo et al. (2010) with slight modifications. Briefly, $500 \mu \mathrm{L}$ of the 
diluted crude extract was mixed with $500 \mu \mathrm{L}$ of 10 -fold diluted Folin-Ciocalteu reagent. After $3 \mathrm{~min}, 400 \mu \mathrm{L}$ of anhydrous sodium carbonate was added and vortexed. The mixture was then incubated for $1 \mathrm{~h}$ in the dark at room temperature. Absorbance was determined at $765 \mathrm{~nm}$ against a blank (deionized water) using a UV/VIS spectrophotometer (Lambda 25, PerkinElmer, Singapore). The measurements were calibrated to a standard curve of a prepared Gallic acid solution $(10-80 \mu \mathrm{g} / \mathrm{mL})$ using the equation $\mathrm{y}=0.0258 \mathrm{x}-$ $0.0716\left(R^{2}=0.9988\right)$ and TPC expressed as milligrams of the Gallic acid equivalent (GAE) per $1 \mathrm{~g}$ of dry weight (DW).

\section{DETERMINATION OF TOTAL FLAVONOID CONTENT (TFC)}

A modified aluminum chloride calorimetric assay as reported by Kaur and Mondal (2014) was used to measure the Total Flavonoid Content (TFC). Briefly, $125 \mu \mathrm{L}$ of the crude extract was mixed with $625 \mu \mathrm{L}$ deionized water and $37.5 \mu \mathrm{L}$ of $5 \%$ sodium nitrate. The mixture was allowed to stand for 6 min and $75 \mu \mathrm{L}$ of $10 \%$ aluminum chloride6-hydrate was added thereafter. After $5 \mathrm{~min}, 250 \mu \mathrm{L}$ sodium hydroxide solution and $137.5 \mu \mathrm{L}$ deionized water was added and mixed. Absorbance was measured at 510 $\mathrm{nm}$ against a blank (deionized water). The measurements were calibrated to a standard curve of a prepared quercetin solution $(0-800 \mu \mathrm{g} / \mathrm{mL})$ using the equation $\mathrm{y}=0.00005 \mathrm{x}$ $+0.0011\left(R^{2}=0.9954\right)$ and TFC expressed as milligrams of quercetin equivalent (QE) per $1 \mathrm{~g}$ dry weight (DW).

\section{DPPH RADICAL SCAVENGING ACTIVITY}

The DPPH scavenging activity was determined according to the protocol suggested by Tan et al. (2013) with slight modifications. A methanolic DPPH stock solution was prepared by dissolving $4 \mathrm{mg}$ 2,2'- diphenyl1-picrylhydrazyl (DPPH) powder into $100 \mathrm{~mL}$ absolute methanol. A working solution was obtained by mixing the $250 \mathrm{~mL}$ stock solution with $100 \mathrm{~mL}$ methanol to obtain an absorbance of $1.00 \pm 0.02$ unit at $517 \mathrm{~nm}$ wavelength. One hundred microliters of the plant extract was mixed with 900 $\mu \mathrm{L}$ of the methanolic DPPH solution and allowed to stand in the dark at room temperature for $30 \mathrm{~min}$. After $30 \mathrm{~min}$ incubation, absorbance was determined at $517 \mathrm{~nm}$ using the UV/VIS spectrophotometer (Lambda 25, PerkinElmer, Singapore) against a blank (methanol).

The percentage of the DPPH scavenging activity was determined using the equation:

DPPH scavenging activity $(\%)=\left[\left(\mathrm{A}_{0}-\mathrm{A}_{30}\right) / \mathrm{A}_{0}\right] * 100$.

where $A_{0}$ is the absorbance at time 0 ; and $A_{30}$ is the absorbance after $30 \mathrm{~min}$.

The DPPH $\mathrm{IC}_{50}$ of the lowest amount of the sample weight that was providing $50 \%$ of the radical scavenging activity was obtained through the linear regression analysis of the standard curve of the samples (10-100 $\mu \mathrm{g} /$ $\mathrm{mL}$ ). Lower $\mathrm{IC}_{50}$ values indicate better radical scavenging activity and vice versa. $\mathrm{IC}_{50}$ was determined to compare effectiveness of antioxidant activities of the crude extracts against the standard antioxidant controls (Ascorbic acid and Trolox).

\section{FERRIC REDUCING ANTIOXIDANT POWER (FRAP)}

The protocols of the FRAP assay were carried out as described by Thaipong et al. (2006). Stock solutions included $300 \mathrm{mM}$ acetate buffer, pH3.6, $10 \mathrm{mM}$ 2,4,6-Tripyridyl-s-triazine (TPTZ) and $20 \mathrm{mM} \mathrm{FeCl}_{3}$. $6 \mathrm{H}_{2} \mathrm{O}$ solution. A fresh FRAP working solution was prepared by mixing acetate buffer, TPTZ solution, and $\mathrm{FeCl}_{3} \cdot 6 \mathrm{H}_{2} \mathrm{O}$ solution in the ratio of $10: 1: 1$, respectively. The FRAP solution was warmed at $37^{\circ} \mathrm{C}$ for $30 \mathrm{~min}$ in a water bath (GFL 1004 Burgwedel, Germany) before use. One hundred microliters of the plant extract were allowed to react with $1000 \mu \mathrm{L}$ of the FRAP solution in the dark for $30 \mathrm{~min}$. The absorbance of the colored product (ferrous tripyridyl triazine complex) was measured at $593 \mathrm{~nm}$ using a UV/VIS spectrophotometer (Lambda 25, Perkin Elmer, Singapore) against a blank (deionized water). The measurements were calibrated to a linear standard curve of a prepared Trolox solution (2500-78.125 $\mu \mathrm{g} / \mathrm{mL})$ using the equation $\mathrm{y}=$ $0.0007 \times-0.0851\left(R^{2}=0.9705\right)$ and the results expressed as milligrams of the trolox equivalent (TE) per $1 \mathrm{~g}$ dry weight (DW).

\section{STATISTICAL ANALYSIS}

The results were expressed as the mean \pm standard deviation of triplicate readings and analyzed using the SPSS software (version 22). One-way analysis of variance (ANOVA) with Duncan's test was carried out to test the significant differences between treatments. $p<0.05$ was considered significant and $p<0.01$ as very significant. Pearson correlations between the variables were also established using the SPSS software (version 22).

\section{RESULTS AND DISCUSSION}

\section{YIELD OF EXTRACTS}

Figure 1 shows the effect of the drying methods and extraction solvents on the extract yields of $S$. ferruginea leaves. As noted, the oven dried $\left(60^{\circ} \mathrm{C}\right)$ mistletoe leaves gave the highest extraction yield while the air dried $\left(27 \pm 1^{\circ} \mathrm{C}\right)$ ones had the lowest. It can be suggested that quick drying of $S$. ferruginea leaves through thermal drying preserved the phenolics and other constituents from degradation via microbial attacks and enzymatic processes, hence increasing the yield. This is supported as reported by Anwar et al. (2013) that oven drying $\left(40^{\circ} \mathrm{C}\right)$ for Brassica oleracea L. extracts for 3 days resulted in a significantly higher extract yield, total phenolic content and antioxidant activity than air drying $\left(25^{\circ} \mathrm{C}\right)$ by using different extracting solvents. Some compounds may be lost in long-term drying at lower temperatures as the water content slowly dries, giving chances for microbes and fungi from the air to affect 


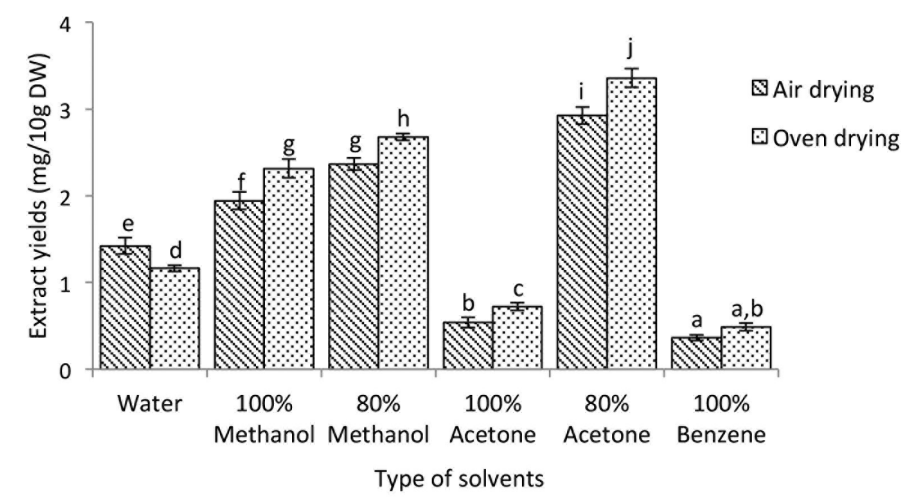

FIGURE 1. Effect of drying methods and extraction solvents on the extract yields of $S$. ferruginea leaves. Values are presented as means $(n=3 \pm \mathrm{SD})$. Values with the same letter superscripts are not significantly different $(p<0.05)$

the plant and reduce the active constituent and shelf life. Zhang et al. (2009) reported that cell wall phenolics or bound phenolics could be released through thermal drying due to the breakdown of cellular constituents, thus causing more yield of the extract. Polyphenol oxidase has also been shown to be denatured and inactivated in thermal drying thus protecting phenolic compounds from being degraded (Zhang et al. 2009). In similar studies, several researchers showed that oven drying $\left(40\right.$ to $80^{\circ} \mathrm{C}$ ) of plants yields the highest content of phenolic compounds (Anwar et al. 2013; Bernard et al. 2014; Ngoc et al. 2015; Rodriguez et al. 2016).

The effectiveness of extracting phenolic antioxidants by using six solvents: deionized water, methanol, $80 \%$ methanol, acetone, $80 \%$ acetone and benzene, from the leaves of the $S$. ferruginea that had been air dried and oven dried, were then evaluated (Figure 1). Altogether, the highest yield based on the solvent was $3.47 \mathrm{mg} / 10 \mathrm{~g}(80 \%$ acetone), $2.72 \mathrm{mg} / 10 \mathrm{~g}$ DW ( $80 \%$ methanol), $2.43 \mathrm{mg} / 10 \mathrm{~g}$ DW (100\% methanol), $1.2 \mathrm{mg} / 10 \mathrm{~g}$ DW (water), $0.77 \mathrm{mg} / 10 \mathrm{~g}$ DW (100\% acetone) and $0.54 \mathrm{mg} / 10 \mathrm{~g}$ DW ( $100 \%$ benzene), respectively. Interestingly, the addition of aqueous water to the organic solvent significantly increased the extract yields. It could be suggested that more phenolic compounds and other bioactive molecules could be obtained with an increase of polarity of the organic solvents with the addition of water. The addition of water to organic solvents could also improve the solubility of more polar compounds by inducing swelling of the cellular matrix, thus improving accessibility of more remote matrix interior sites (Shams et al. 2015). Diem et al. (2013) reported an increase in extract yield using different proportions and combinations of organic solvents with aqueous solvents as against pure organic solvents (ethanol, methanol and acetone) in Limnophila aromatica extracts; yet, increasing the water content to $50 \%$ caused the phenolic compound and antioxidant activity to be decreased. In a related study by Anwar and Przybylski (2012) on Linum usitatissimum L., $80 \%$ methanol gave the highest yield, but the extract did not contain the highest amount of phenolics and flavonoids. However, when $80 \%$ ethanol was used for the extraction, the highest amount of the flavonoids was detected and also the best antioxidant capacity. A similar study by Butsat and Siriamornpun (2016), showed that a higher recovering amount of extract yields was achieved through $80 \%$ methanol which also produced higher phenolic and antioxidant activity compared to other conditions tested. This is in agreement with our findings.

\section{TOTAL PHENOLIC CONTENT}

The effect of the drying methods and extraction solvents on the total phenolic content (TPC) in the $S$. ferruginea leaves is shown in Figure 2. Generally, it was observed that there was almost no significant difference $(p<0.05)$ between the drying methods tested on the TPC values. From an economical point of view, oven drying was chosen because of its benefit in saving time and cost output in the drying process. Kankara et al. (2014) and Mediani et al. (2014) reported that enzymatic processes caused by the thermal treatments degraded the phenolics in Guiera senegalensis and Cosmos caudatus leaves, respectively. However, in our current studies, the phenolic compounds in this plant were better when dried in an oven $\left(60^{\circ} \mathrm{C}\right)$ and possessed strong antioxidant activity. Based on this premise, we infer that the drying process may also be influenced by the morphological characteristics of the leaves, such as size, thickness and leaf modifications, that may possibly protect the phenolic compounds from being degraded during fast thermal treatment. The morphological distinctive features of the S.ferruginea, such as small, waxy and hairy leaves, gave it disadvantages in the air drying because of the cuticle that is coated with waxy and hairy ferruginous layer which may cause break-off of the water loss through the epidermis thus exposing the plant cells to microbial attack and enzymatic processes. Besides that, a smaller surface area and thin leaves also encourage less water loss in the leaf cells. Fast thermal drying is important for the preservation of active constituents, such as phenolics, in $S$. ferruginea leaves since these compounds help to halt the enzymatic process and microbial attack from occurring 
by reducing the moisture content rapidly. Previous studies have shown that the highest content of phenolics was reported in maqui berries (Aristotelia chilensis) using the oven drying $\left(60^{\circ} \mathrm{C}\right)$ method (Rodriguez et al. 2016), which is in agreement with our results. Likewise, Roshanak et al. (2015) showed that oven drying at $60^{\circ} \mathrm{C}$ and $100^{\circ} \mathrm{C}$ led to the highest TPC in green tea (Camellia sinensis or C. assamica) leaves. Anwar et al. (2013) and Hong Ngoc et al. (2015) also showed that oven drying at $40^{\circ} \mathrm{C}$ and oven drying at $50^{\circ} \mathrm{C}$ or $80^{\circ} \mathrm{C}$, respectively, retained the highest content of the total phenolics than other drying methods.

Figure 2 also shows that the extraction solvents significantly $(p<0.05)$ affected the TPC values. The TPC acquired ranged from $103.61 \mathrm{mg} \mathrm{GAE} / 1 \mathrm{~g}$ DW to $179.07 \mathrm{mg}$ GAE/1g DW. The highest TPC (179.07 mg GAE/1g DW) was observed in $100 \%$ acetone extract. Eighty percent acetone (171.29 mg GAE/1g DW) and 80\% methanol (168.18 mg GAE/1g DW) showed no significant difference. The lowest TPC was observed in $100 \%$ benzene extract $(108.95$ $\mathrm{mg} \mathrm{GAE} / 1 \mathrm{~g} \mathrm{DW})$. Generally, polar types of organic and aqueous organic solvents ( $80 \%$ methanol, $100 \%$ acetone, $80 \%$ acetone) were shown to be the most effective in recovering a greater amount of TPC. This highlights the abundance of these secondary metabolites in the $S$. ferruginea leaf extracts. The complexity of the chemical characteristics and polarities of the phenolic compounds in plants make them soluble and insoluble in a particular solvent. These data are in agreement with those obtained in previous studies by Marvibaigi et al. (2014) that showed a high total phenolic content (310.22 mg GAE/1g DW) in the $S$. ferruginea stem extracted with an $80 \%$ acetone solvent. In another study, a significant amount of TPC (34.2 g GAE/100g DW) was found in acetone using different kinds of solvent (methanol, ethanol, acetone and ethyl acetate) extractions (Anokwuru et al. 2011). Several other studies have also shown that the phenolic compounds in some plants are extracted better using organic solvents, particularly the polar solvents $(60 \%$ methanol, 80\% methanol and 80\% ethanol) (Bouterfas et al. 2014; Shabir et al. 2011; Sultana et al. 2009).

\section{TOTAL FLAVONOID CONTENT}

The total flavonoid content (TFC) in the $S$. ferruginea leaves was significantly $(p<0.05)$ influenced by the drying methods as presented in Figure 3. Though the air drying extracts possessed a higher TFC, oven drying extracts were chosen as the overall considerations via the extract yield and TPC outcomes. In the overall outcomes, it is interesting that the amount of TFC declined in oven drying which varied from the TPC results. It can be suggested that the TFC is a thermolabile compound that can be easily degraded and decreased in thermal drying. During hightemperature drying, moisture content is reduced through the secretion of water vapor in the leaf cellular matrix and this also affects the resistance of the cell structure to leakage or breakdown which results in the loss of volatile phytochemicals via chemical reactions like with enzymes, light and oxygen (Zainol et al. 2009). Many other researchers have reported the degradation of TFC when exposed to thermal treatment. Similar to the present study, Kankara et al. (2014) found significant reduction of TFC in Guiera senegalensis leaves when oven dried for $12 \mathrm{~h}$ at $75^{\circ} \mathrm{C}$. Zhou et al. (2011) showed significant decline of flavonoid and total phenolic contents using oven drying $\left(60^{\circ} \mathrm{C}, 80^{\circ} \mathrm{C}\right.$ and $\left.100^{\circ} \mathrm{C}\right)$ compared to high-powered microwave drying and freeze drying in Eriobotrya japonica Lindl. flowers. Furthermore, some other researchers also reported a significant decrease in TFC for particular plant species using oven drying; at the same time, preserving TPC and TFC the freeze drying process (Ibrahim et al. 2013; Irondi et al. 2013; Rabeta \& Lin 2015).

Figure 3 shows that the TFC in the extracts were significantly $(p<0.05)$ affected by the extraction solvents. The results showed that the TFC in the extracts ranged from $14.75 \mathrm{mg} \mathrm{QE} / 1 \mathrm{~g}$ DW to $112.48 \mathrm{mg} \mathrm{QE} / 1 \mathrm{~g}$ DW. The $100 \%$ acetone extract gave the highest TFC $(112.48 \mathrm{mg}$

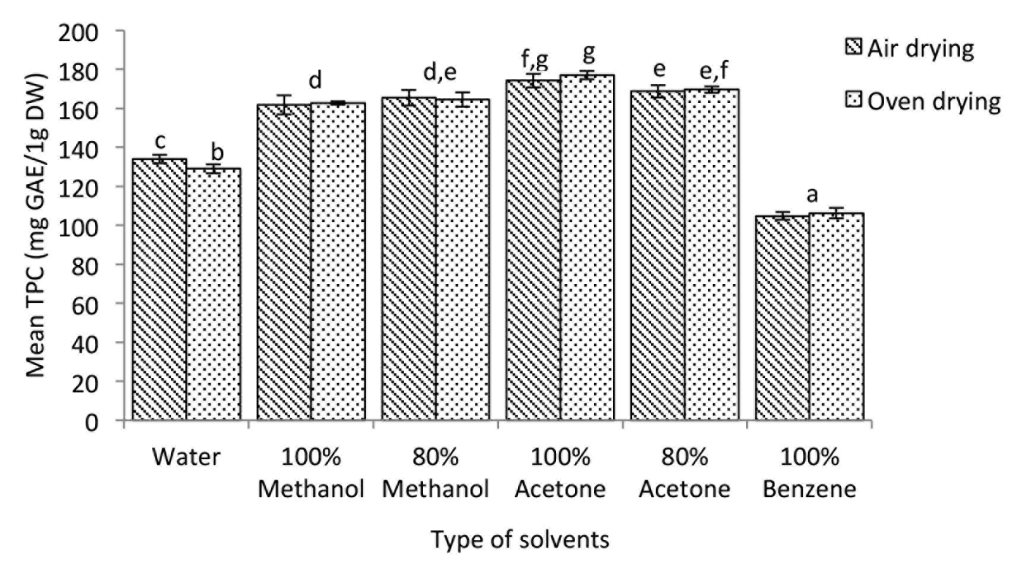

FIGURE 2. Effect of drying methods and extraction solvents on the Total Phenolic Content (TPC) of $S$. ferruginea leaf extracts. Values are presented as means $(n=3 \pm \mathrm{SD})$. Values with the same letter superscripts are not significantly different $(p<0.05)$ 


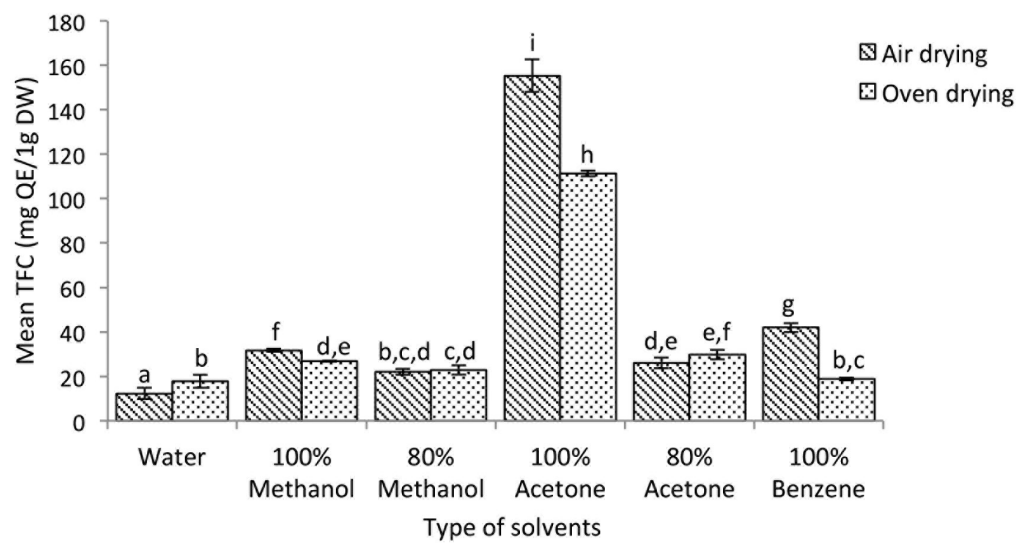

FIGURE 3. Effect of drying methods and extraction solvents on the Total Flavonoid Content (TPC) of $S$. ferruginea leaf extracts. Values are presented as means $(n=3 \pm \mathrm{SD})$.

Values with the same letter superscripts are not significantly different $(p<0.05)$

QE/1g DW) followed by $80 \%$ acetone $(31.91 \mathrm{mg} \mathrm{QE} / 1 \mathrm{~g}$ DW) and $80 \%$ methanol $(27.14 \mathrm{mg} \mathrm{QE} / 1 \mathrm{~g} \mathrm{DW})$ while the lowest TFC was observed in the water extracts $(20.73 \mathrm{mg}$ $\mathrm{QE} / 1 \mathrm{~g} \mathrm{DW})$. These findings show that the TFC is effectively more extractible by $100 \%$ acetone which is a semi-polar solvent. This may be due to the fact that the $S$.ferruginea leaf extracts consisted of many semi-polar flavonoid compounds. Extraction solvents play a significant role in the extraction of active substances because of the diversity of the polarities of the phytochemicals in their cellular matrixes. Thus, a variety of solvents have been used from aqueous solvents, organic solvents and aqueous organic solvents to obtain the highest amount of the targeted compound. This study is alike to previous reports by Assanga et al. (2015) in which the highest total phenolic and flavonoid contents were observed in Phoradendron californicum with $575.35 \mu \mathrm{g}$ GAE/mg extract and 432.74 $\mu \mathrm{g} \mathrm{GAE} / \mathrm{mg}$ extract for methanol and aqueous fractions, respectively. On the other hand, Bucida buceras stems held the highest flavonoid content $(258.523 \mu \mathrm{g}$ PNE/mg) in the acetone extracts. Similarly, Shabir et al.(2011) stated that the total flavonoid contents, total phenolic contents and antioxidant compounds were more extractable using $80 \%$ methanol for the Delonix regia leaf extracts. Other than that, the findings related to the optimization of flavonoids for Tagetas patula flowers also showed that the acetone extract had the highest TFC and the best radical scavenging activity (Leite et al. 2014).

\section{DPPH RADICAL SCAVENGING ACTIVITY}

As seen in Figure 4, there was almost no significant difference $(p<0.05)$ in the antioxidant activity of the extracts using the drying methods (air and oven drying). Yet, a slightly higher DPPH value was obtained in the extraction solvents used for the oven dried treatment than for the air dried treatment except for the $100 \%$ acetone extracts. Therefore, oven drying appears to be the best preservation method for antioxidant activity in the $S$. ferruginea leaves. It can thus be suggested that the phenolic compounds of the $S$. ferruginea leaves are linked to the antioxidant activity mainly in the TPC. It is well known, that most of the plant secondary metabolites, which are in the phenolic group, contain a mixture of active constituents that are responsible for the antioxidant activity. The result for the highest DPPH radical scavenging activity in the leaves could be explained by the presence of a high concentration of phenolics in the $S$. ferruginea leaves as supported by the evidence from the previous studies by Mohammed et al. (2014) and Stankovi (2011), with both studies showing the phenolic compounds to be responsible for the strong antioxidant activity in Malva sylvestris L. leaves and Marrubium peregrinum L. extracts, respectively. Some of the phenolic compounds were from tannin, steroids, coumarins, lignans and quinone (Cai et al. 2004; Rodriguez et al. 2016). Other constituents such as protein, lipid and carbohydrates that function as hydrogen donors also significantly affect the antioxidant activity (Jakobek 2015).

The results of DPPH radical scavenging activity of $S$. ferruginea leaf extracts as affected by the extraction solvents $(p<0.05)$ is presented in Figure 4 . The results showed that $100 \%$ methanol, $80 \%$ methanol, $100 \%$ acetone and $80 \%$ acetone extracts possessed a higher DPPH radical scavenging activity compared to the $100 \%$ benzene and water extracts. In detail, the extracts for the $80 \%$ methanol gave the highest DPPH values (94\%) followed by the $80 \%$ acetone $(93.2 \%)$ while the lowest values were observed in the benzene $(42.1 \%)$. As expected, the standard antioxidant, Trolox, exhibited the highest DPPH radical scavenging activity $(95.7 \%)$ compared to ascorbic acid (91.4\%) and other extracts. Organic solvents (100\% methanol and $100 \%$ acetone) and aqueous organic solvents ( $80 \%$ methanol and $80 \%$ acetone) possess strong antioxidant activity at $100 \mu \mathrm{g} / \mathrm{mL}$ inhibiting DPPH free radicals. The ability of the organic solvent to penetrate the cell matrix and solubilize the concoction therapeutic compound makes it a favored solvent for extracting antioxidants in plants. It also has advantages in protecting active constituents from microbial attacks compared to 


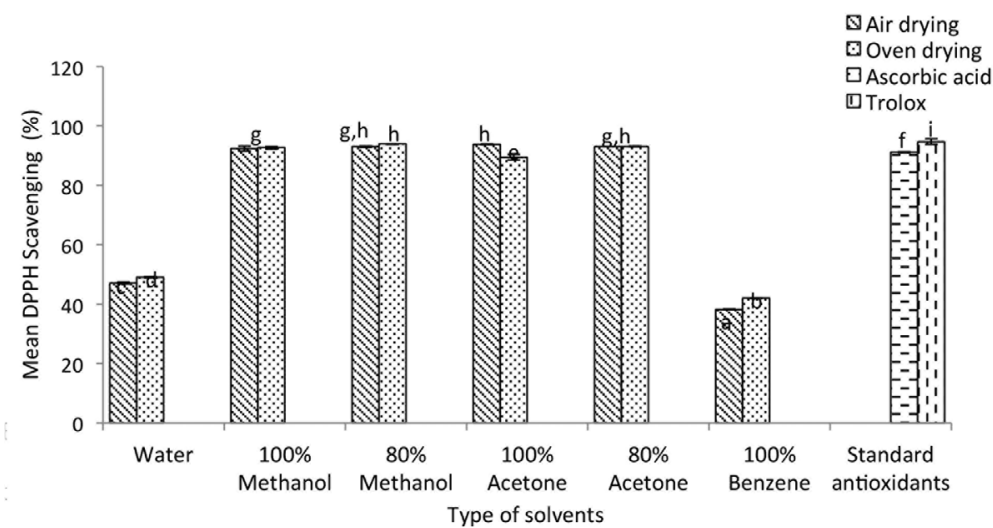

FIGURE 4. Effect of drying methods and extraction solvents on the DPPH radical scavenging (\%) of $S$. ferruginea leaf extracts. Values are presented as means $(n=3 \pm \mathrm{SD})$.

Values with the same letter superscripts are not significantly different $(p<0.05)$

an aqueous solvent that can becomes a medium for the growth of microbes. Also, the promising antioxidant activity in water added organic solvents is caused by the high polar solvent of the water that has the capability to enter and swell the cell surroundings, thus resulting in the leakage of the cell induced extracted compound into the remote matrix (Durante et al. 2014; Shams et al. 2015). This finding is in agreement with previous results reported by Mohammedi and Atik (2011) that showed the crude extract of the leaves from Tamarix aphylla obtained with aqueous acetone presented a strong and potent scavenging capacity against free radical DPPH; even so, it has recorded the lowest content of phenolic compounds as matched with other aqueous organic solvents (70\% ethanol, 70\% methanol,). Likewise, Siddhuraju and Becker (2003) also ascertained that $80 \%$ methanol and $80 \%$ ethanol were found to be the finest solvents for the extraction of antioxidant compounds from Moringa oleifera Lam. leaves. Moreover, several studies showed that aqueous organic solvent (50\% acetone) produced strong extraction power and antioxidant activity (Musa et al. 2011; Zhou \& Yu 2004).

It should be noted that a lower $\mathrm{IC}_{50}$ value signifies more potent inhibition of the free radicals, where strong free radical inhibitors are active at low concentrations. The $\mathrm{IC}_{50}$ of the leaf extracts of $S$. ferruginea as affected by the drying methods and extraction solvents $(p<0.05)$ is presented in Figure 5. From this figure, it is shown that the oven dried leaves extracted by different solvents were identified as having the best antioxidant activity because it has better inhibiting $\mathrm{DPPH}$ radicals at $\mathrm{IC}_{50}$. The half maximal inhibitory concentration $\left(\mathrm{IC}_{50}\right)$ values in the oven dried leaf extracts showed that the lowest $\mathrm{IC}_{50}$ values obtained were $80 \%$ acetone $(7.41 \mu \mathrm{g} / \mathrm{mL})$ followed by $80 \%$ methanol $(19.31 \mu \mathrm{g} / \mathrm{mL})$; while, the highest were found in $100 \%$ benzene $(469.15 \mu \mathrm{g} / \mathrm{mL})$. Interestingly, no significant difference was seen in the $\mathrm{IC}_{50}$ values using $100 \%$ methanol, $80 \%$ methanol, 100\% acetone, $80 \%$ acetone, ascorbic acid and Trolox. It could be suggested that more phenolic compounds are preserved in thermal drying compare to air drying, as a result, the preserved bioactive constituents in $S$. ferruginea leaves contributing to the higher antioxidant activity in the $\mathrm{IC}_{50}$ values. Rodriguez et al. (2016) reported that the highest antioxidant activity was observed in Aristotelia chilensis berries at $60^{\circ} \mathrm{C}$ and $70^{\circ} \mathrm{C}$ of drying, which is in agreement with this study. Abdullah et al. (2011) also reported a similar view as in our current study, where the total antioxidant activity of Orthosiphon staminiues leaf extract increased with the oven temperatures $\left(70^{\circ} \mathrm{C}\right)$. As noted before, the antioxidant activity of the $S$.ferruginea may be assisted by other hydrogen donating constituents, such as sugar and other compounds that are persevered with thermal drying. In view of this, shortening the duration of the drying period by using thermal temperatures for $S$. ferruginea leaves is vital for better quality and time savings. Findings from this study suggest that the extracts of $S$. ferruginea possess a hydrogen donating ability and could serve as free radical inhibitors or scavengers, acting possibly as primary antioxidants. This is supported by Shabir et al. (2011) that reported strong antioxidant activity in $80 \%$ methanol extracts of Delonix regia leaves by scavenging DPPH free radicals at the $\mathrm{IC}_{50}$ value of 8.89 $\mu \mathrm{g} / \mathrm{mL}$. In addition, Assanga et al. (2015) quantified the potent $\mathrm{IC}_{50}$ activity in total of $3.69 \mu \mathrm{g} / \mathrm{mL}$ of the acetone extracts for Bucida buceras trunks. Some authors also reported lower DPPH $\mathrm{IC}_{50}$ values inhibiting the DPPH free radicals using different extraction solvents (Diem et al. 2013; Norziah et al. 2015).

\section{FRAP ASSAY}

The effect of drying methods on the ferric reducing antioxidant power (FRAP) of the $S$. ferruginea leaves is shown in Figure 6. Figure 6 shows that the drying methods did not significantly $(p<0.05)$ affect the FRAP activity in most extract solvents, though $80 \%$ methanol showed significant differences $(p<0.05)$. Thus, oven drying was selected for the following process as accorded with the better antioxidant activity in the DPPH 


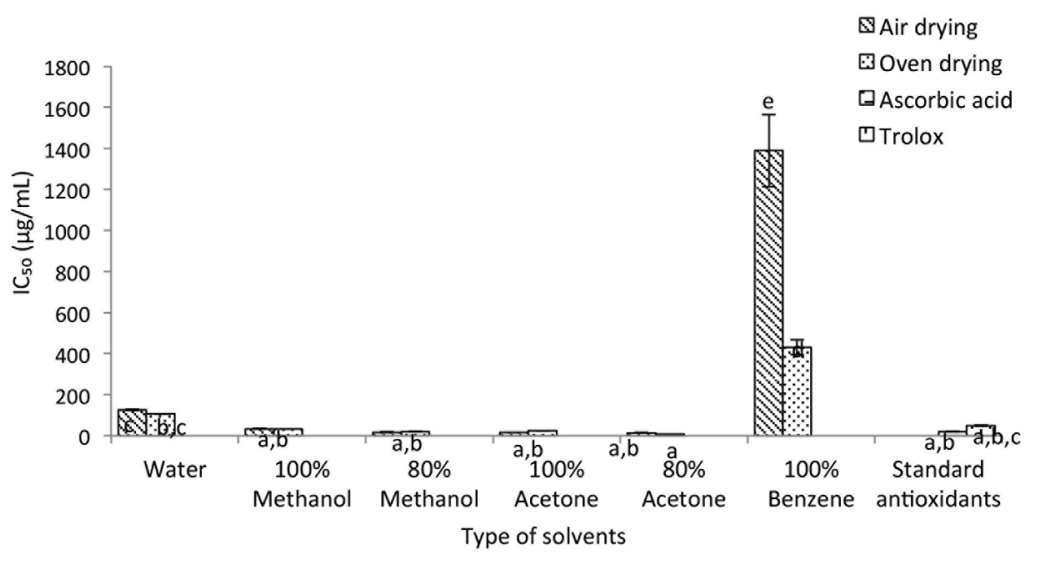

FIGURE 5. Effect of drying methods and extraction solvents on the DPPH inhibition concentration, $50 \%\left(\mathrm{IC}_{50}\right)$, of $S$. ferruginea leaf extracts. Values are presented as means $(n=3 \pm \mathrm{SD})$. Values with the same letter superscripts are not significantly different $(p<0.05)$

radical scavenging and $\mathrm{IC}_{50}$ activity. Plant phenolics are produced as a defense mechanism by biotic and abiotic stress responses, such as wounds, high temperatures and attack by pathogens (Hossain et al.2010). Morphological characteristics of the $S$. ferruginea leaves have a set of cellular and metabolic responses that may preserve phenolic compounds (which contains an electron donating antioxidant), from a deterioration under thermal drying conditions. Therefore, the antioxidant constituent ability of this plant is preserved better at high temperatures than the low temperatures present during the air drying process. Moreover, the increase in the FRAP value observed in the oven dried sample extracted with $80 \%$ methanol could have been a result of cell membrane degradation based on the thermal treatment that causes enzymatic releases of bound phenolic compounds, thereby resulting in higher antioxidant activity (Yi \& Wetzstein 2011). Previous studies by Butsat and Siriamornpun (2016) and Yakob et al. (2012) showed that $80 \%$ methanol exhibited the highest FRAP values compared to other solvents, which supported the results of our studies.

Figure 6 shows that the extraction solvent significantly affected $(p<0.05)$ the FRAP activity in the S. ferruginea leaf extract. The highest FRAP activity was unveiled in the $80 \%$ methanol extracts followed by the $100 \%$ methanol extracts with $27.86 \mathrm{mg}$ TE/1g DW and $27.50 \mathrm{mg}$ TE/1g DW, respectively. Whereas, the $100 \%$ benzene extracts exhibited the lowest FRAP activity with $1.71 \mathrm{mg}$ TE/1g DW. The present study demonstrated that $80 \%$ methanol exhibited the highest FRAP values, yet there were no significant differences shown among the $100 \%$ methanol, $100 \%$ acetone and $80 \%$ acetone, respectively. This thus suggests that the antioxidant activity of the S.ferruginea leaf extracts is likely to be in accordance with content of the phenolics. Phenolic compounds expose extensive free radical scavenging activities through their reactivity as hydrogen or electron-donating agents and metal ion chelating properties (Ghafar et al. 2010). The findings by Butsat and Siriamornpun (2016) on Amomum chinense leaf extracts showed the optimal conditions, which provided a higher number of phenolic compounds and antioxidant activity (DPPH, FRAP and ABTS), were $80 \%$ methanol for $12 \mathrm{~h}$. This is in agreement with findings from this study. The diverse antioxidant constituent polarities in the $S$.ferruginea leaf extracts are mainly in polar compounds making them extractible with different kinds of polar aqueous organic solvents. The findings of this study are not surprising as Yakob et al. (2012) reported that $80 \%$ methanol solvents were able to unveil high FRAP activity (1256.88 $\mu \mathrm{M}$ TE/mg DW) in Ludwigia octovalvis leaves, which is similar with the results from this study. Likewise, a number of studies carried out using different ratio combinations of organic solvents (ethanol, methanol and acetone) with water show greater recovery of antioxidant activity (Alothman et al. 2009; Mashkor 2014).

\section{CORRELATION OF TPC, TFC, DPPH, FRAP AND EXTRACT YIELD}

The correlation study analysis is presented in Table 1 . There is a strong correlation among TPC, TFC $(p<0.05)$, DPPH $(p<0.01)$, FRAP $(p<0.01)$ and extract yield $(p<0.01)$. In view of this, it can be postulated that a higher extract yield indicates a higher phenolic compound and strong antioxidant activity as more extract yield is accumulated. Besides the phenolic compounds, vitamins, proteins and minerals are also increased and may therefore contribute indirectly to a better antioxidant activity. This is in agreement with previous research findings that indicate that there is a direct correlation between the total phenolics, antioxidant activity and extract yield (Anwar et al.2013). Phongtongpasuk and Poadang (2014) also reported that there is a high correlation among TPC, antioxidant activity and extract yield of Peperomia pellucid L. Kunth. Phenolic compounds are responsible for the superior antioxidant activity, although the flavonoid content was not significantly different between the DPPH and FRAP. This is further supported by findings from previous studies; for 


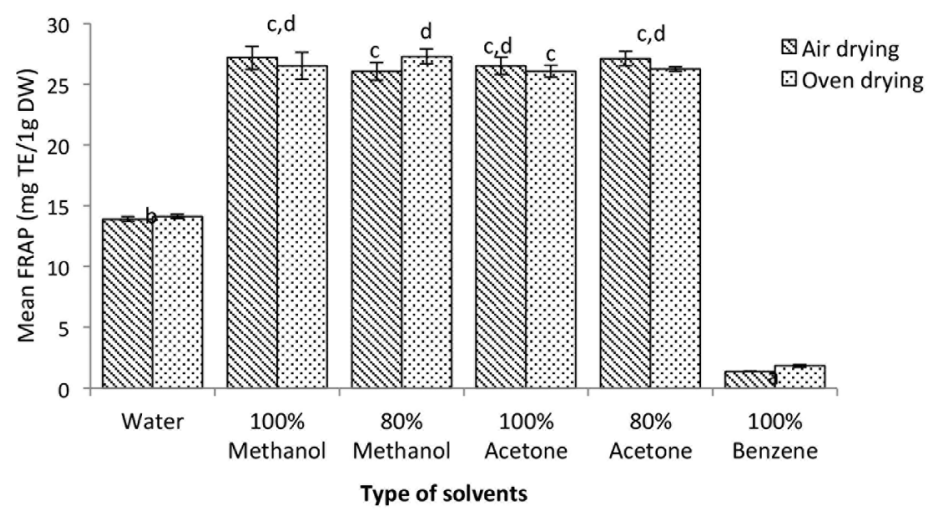

FIGURE 6. Effect of drying methods and extraction solvents on Ferric Reducing Antioxidant

Power (FRAP) of $S$. ferruginea leaf extracts. Values are presented as means $(n=3 \pm \mathrm{SD})$.

Values with the same letter superscripts are not significantly different $(p<0.05)$

TABLE 1. Correlation between phenolic compound, antioxidant activities and extract yield of $S$. ferruginea leaf extracts $(n=3)^{\mathrm{y}}$

\begin{tabular}{ccccc}
\hline $\mathrm{r}$ & $\mathrm{TPC}$ & $\mathrm{TFC}$ & $\mathrm{DPPH}$ & FRAP \\
\hline $\mathrm{TFC}$ & $.411 *$ & & & \\
$\mathrm{DPPH}$ & $.953 * *$ & .315 & & \\
FRAP & $.971 * *$ & .264 & $.957 * *$ & \\
Yield & $.550 * *$ & $-.462 * *$ & $.623 * *$ & $.644 * *$ \\
\hline
\end{tabular}

y replications, $r$ correlation coefficient, TPC, total phenolic content; TFC, total flavonoid content; DPPH, DPPH radical scavenging activity; FRAP, ferric reducing antioxidant power, Yield, yield of crude extract. *Significant level at $p<0.05$ and $* *$ Significant level at $p<0.01$

example, Adedapo et al. (2008) observed that total phenols were highly positive in correlation with the antioxidant activity in most of the plant species. Furthermore, a weak but highly significant correlation $(r=-0.462)$ was also observed between the extract yield and TFC as affected by different solvents. From this, it can be deduced that total flavonoids are minor contributors to antioxidant activity compared to total phenolics. Previous studies also reported a negative correlation $(r=-0.229)$ between the extract yield and flavonoids in Azadirachta indica stem (Anokwuru et al. 2011).

\section{CONCLUSION}

The best drying method and extraction solvents for extracting phenolics and antioxidant activity from $S$. ferruginea leaves were determined here. Oven drying $\left(60^{\circ} \mathrm{C}\right)$ using $80 \%$ acetone gave the optimum extract yield, content of phenolic compounds (TPC and TFC) and antioxidant activities (DPPH and FRAP). A correlation study revealed significant positive correlations among the TPC, TFC $(p<0.05)$, DPPH $(p<0.01)$, FRAP $(p<0.01)$ and extract yield $(p<0.01)$ under the influence of the drying methods and extraction solvents. Findings from the present study suggest that drying methods used in sample preparation and the use of different solvents for extraction of bioactive compounds play critical roles to improve the efficiency and efficacy of $S$.ferruginea leaf extracts as potent antioxidant source.

\section{REFERENCES}

Abdullah, S., Ahmad, M.S., Shaari, A.R. \& Johar, H.M. 2011. Drying characteristics and herbal metabolites composition of Misai Kucing (Orthosiphon staminiues Benth.) leaves. International Conference on Food Engineering and Biotechnology 9: 305-309.

Adedapo, A.A., Jimoh, F.O., Koduru, S., Afolayan, A.J. \& Masika, P.J. 2008. Antibacterial and antioxidant properties of the methanol extracts of the leaves and stems of Calpurnia aurea. BMC Complementary and Alternative Medicine 8(1): 53.

Alimpić, A., Oaldje, M., Matevski, V., Marin, P.D. \& DuletićLaušević, S. 2014. Antioxidant activity and total phenolic and flavonoid contents of Salvia amplexicaulis Lam. extracts. Archives of Biological Sciences 66(1): 307-316.

Alothman, M., Bhat, R. \& Karim, A.A. 2009. Antioxidant capacity and phenolic content of selected tropical fruits from Malaysia, extracted with different solvents. Food Chemistry 115(3): 785-788.

Anokwuru, C.P., Anyasor, G.N., Ajibaye, O., Fakoya, O. \& Okebugwu, P. 2011. Effect of extraction solvents on phenolic, flavonoid and antioxidant activities of three nigerian medicinal plants. Nature and Science 9(7): 53-61.

Anwar, F., Kalsoom, U., Sultana, B., Mushtaq, M., Mehmood, T. \& Arshad, H.A. 2013. Effect of drying method and extraction solvent on the total phenolics and antioxidant activity of 
cauliflower (Brassica oleracea L.) extracts. International Food Research Journal 20(2): 653-659.

Anwar, F. \& Przybylski, R. 2012. Effect of solvents extraction on total phenolics and antioxidant activity of extracts from Flaxseed (Linum usitatissimum L.). Acta Scientiarum Polonorum, Technologia Alimentaria 11(3): 293-301.

Assanga, S.B.I., Luján, L.M.L., Espinoza, C.L.L., Salido, A.A.G., Angulo, D.F., Pino, J.L.R. \& Haines, D.D. 2015. Solvent effects on phytochemical constituent profiles and antioxidant activities , using four different extraction formulations for analysis of Bucida buceras L. and Phoradendron californicum. BMC Research Notes 396(8): 1-14.

Bernard, D., Kwabena, A.I., Osei, O.D., Daniel, G.A., Elom, S.A. $\&$ Sandra, A. 2014. The effect of different drying methods on the phytochemicals and radical scavenging activity of Ceylon Cinnamon (Cinnamomum zeylanicum) plant parts. European Journal of Medicinal Plants 4(11): 1324-1335.

Bouterfas, K., Mehdadi, Z., Benmansour, D. \& Khaled, M.B. 2014. Optimization of extraction conditions of some phenolic compounds from White Horehound (Marrubium vulgare L.) leaves. International Journal of Organic Chemistry 4(12): 292-308.

Burkill, I.H. 1966. A Dictionary of the Economic Products of the Malay Peninsula (Vol. 2). Kuala Lumpur: Ministry of Agriculture and Co-operatives.

Butsat, S. \& Siriamornpun, S. 2016. Effect of solvent types and extraction times on phenolic and flavonoid contents and antioxidant activity in leaf extracts of Amomum chinense C. International Food Research Journal 23(1): 180-187.

Cai, Y., Luo, Q., Sun, M. \& Corke, H. 2004. Antioxidant activity and phenolic compounds of 112 traditional chinese medicinal plants associated with anticancer. Life Sciences 74(17): 21572184.

de Freitas Araújo, M.G. \& Bauab, T.M. 2012. Microbial quality of medicinal plant materials. In Latest Research into Quality Control, edited by I. Akyar. Crotia: In Tech Europe. pp. 67-81.

Diem, Q., Elisa, A. \& Tran-nguyen, P.L. 2013. Effect of extraction solvent on total phenol content, total flavonoid content, and antioxidant activity of Limnophila aromatica. Journal of Food and Drug Analysis 22(3): 296-302.

Durante, M., Lenucci, M.S., D’Amico, L., Piro, G. \& Mita, G. 2014. Effect of drying and co-matrix addition on the yield and quality of supercritical $\mathrm{CO}_{2}$ extracted Pumpkin (Cucurbita moschata Duch.) oil. Food Chemistry 148: 314-320.

Garcia-salas, P., Morales-soto, A., Segura-carretero, A. \& Fernández-gutiérrez,A. 2010. Phenolic-compound-extraction systems for fruit and vegetable samples. Molecules 15: 88138826.

Ghafar, M.F.A., Prasad, K.N., Weng, K.K. \& Ismail, A. 2010. Flavonoid, hesperidine, total phenolic contents and antioxidant activities from Citrus species. African Journal of Biotechnology 9(3): 326-330

Hossain, M.B., Barry-Ryan, C., Martin-Diana, A.B. \& Brunton, N.P. 2010. Effect of drying method on the antioxidant capacity of six Lamiaceae herbs. Food Chemistry 123(1): 85-91.

Ibrahim, N.M., Mat, I., Lim, V. \& Ahmad, R. 2013. Antioxidant activity and phenolic content of Streblus asper leaves from various drying methods. Antioxidants 2: 156-166.

Irondi, A.E., Anokam, K.K. \& Ndidi, U.S. 2013. Effect of drying methods on the phytochemicals composition and antioxidant activities of Carica papaya seed. International Journal of Biosciences 3(11): 154-163.
Ismail,H.I.,Chan, K.W.,Mariod,A.A. \& Ismail, M. 2010. Phenolic content and antioxidant activity of Cantaloupe (Cucumis melo) methanolic extracts. Food Chemistry 119(2): 643-647.

Jakobek, L. 2015. Interactions of polyphenols with carbohydrates, lipids and proteins. Food Chemistry 175: 556-567.

Kankara, S.S., Mustafa, M., Ibrahim, H.M., Nulit, R. \& Go, R. 2014. Effect of drying methods, solid-solvent ratio, extraction time and extraction temperature on phenolic antioxidants and antioxidant activity of Guiera senegalensis J.F. Gmel (Combretaceae) leaves water extract. American Journal of Phytomedicine and Clinical Therapeutics 2(12): 1378-1392.

Kaur, S. \& Mondal, P. 2014. Study of total phenolic and flavonoid content, antioxidant activity and antimicrobial properties of medicinal plants. Journal of Microbiology \& Experimentation 1(1): 1-6.

Khoddami, A., Wilkes, M.A. \& Roberts, T.H. 2013. Techniques for analysis of plant phenolic compounds. Molecules 18(2): 2328-2375.

Leite, E.V.S., Lopes, G.C. \& Mello, J.C.P. 2014. Extraction of flavonoids from Tagetes patula: Process optimization and screening for biological activity. Brazilian Journal of Pharmacognosy 24: 576-583.

Lemmens, R.H.M.J. \& Bunyapraphatsara, N. 2003. Plant Resources of South-East Asia: Medicinal and Poisonous Plants 3. Leiden, The Netherlands: Backhuys Publishers.

Mahmoudi, S., Khali, M., Benkhaled, A., Benamirouche, K. \& Baiti, I. 2015. Phenolic and flavonoid contents, antioxidant and antimicrobial activities of leaf extracts from ten Algerian Ficus carica L. varieties. Asian Pacific Journal of Tropical Biomedicine 6(3): 239-245.

Maruyama, K. \& Iso, H. 2014. Overview of the role of antioxidant vitamins as protection against cardiovascular disease: Implications for aging. In Aging: Oxidative Stress and Dietary Antioxidants, edited by Preedy, V.R. London, UK: Elsevier. pp. 213-224.

Marvibaigi, M.,Amini, N., Supriyanto, E., Jamil, S., Abdul Majid, F.A. \& Khangholi, S. 2014. Total phenolic content, antioxidant and antibacterial properties of Scurrula ferruginea extracts. Jurnal Teknologi 70(5): 65-72.

Mashkor, I. \& Muhson, A.A. 2014. Total phenol, total flavonoids and antioxidant activity of pomegranate peel. International Journal of ChemTech Research 6(11): 4656-4661.

Mat-Salleh, K. \& Latiff, A. 2002. Tumbuhan Ubatan Malaysia. Bangi, Selangor: Pusat Pengurusan Penyelidikan UKM.

Mediani, A., Abas, F., Tan, C. \& Khatib, A. 2014. Effects of different drying methods and storage time on free radical scavenging activity and total phenolic content of Cosmos Caudatus. Antioxidants 3(2): 358-370.

Mohammed, C.B., Chahid, B., Fatima, B., Fatima-Zohra, S., Meriem, B. \& Farid, C. 2014. Antioxidant activity, phenolic and flavonoid content in leaves, flowers, stems and seeds of mallow (Malva sylvestris L.) from North Western of Algeria. African Journal of Biotechnology 13(3): 486-491.

Mohammedi, Z. \& Atik, F. 2011. Impact of solvent extraction type on total polyphenols content and biological activity from Tamarix aphylla (L.) Karst. International Journal of Pharma and Bio Sciences 2(1): 609-615.

Musa, K.H., Abdullah, A., Jusoh, K. \& Subramaniam, V. 2011. Antioxidant activity of pink-flesh Guava (Psidium guajava L.): Effect of extraction techniques and solvents. Food Analytical Methods 4: 100-107.

Hong Ngoc Thuy Pham, Van Tang Nguyen, Quan Van Vuong, Bowyer, M.C. \& Scarlett, C.J. 2015. Effect of extraction solvents and drying methods on the physicochemical and 
antioxidant properties of Helicteres hirsuta Lour. leaves. Technologies 3: 285-301.

Norziah, M.H., Fezea, F.A., Bhat, R. \& Ahmad, M. 2015. Effect of extraction solvents on antioxidant and antimicrobial properties of Fenugreek seeds (Trigonella foenum-graecum L.). International Food Research Journal 22(3): 1261-1271.

Obeidat, M., Shatnawi, M.,Al-alawi, M.,Al-Zu'bi, E.,Al-Dmoor, H., Al-Qudah, M., Qudah, J. \& Otri, I. 2012. Antimicrobial activity of crude extracts of some plant leaves. Research Journal of Microbiology 7(1): 59-67.

Onivogui, G., Letsididi, R., Diaby, M., Wang, L. \& Song, Y. 2015. Influence of extraction solvents on antioxidant and antimicrobial activities of the pulp and seed of Anisophyllea laurina $\mathrm{R}$. Br. ex Sabine fruits. Asian Pacific Journal of Tropical Biomedicine 6(1): 1-6.

Phongtongpasuk, S.\& Poadang, S. 2014. Extraction of antioxidants from Peperomia pellucid L. Kunth. Thammasat International Journal of Science and Technology 19(3): 38-43.

Puneetha, G.K., Murali, M., Thriveni, M.C. \& Amruthesh, K.N. 2014. Phytochemical screening, antioxidant and antibacterial properties of Taxillus cuneatus (Roth.) Danser - a hemiparasitic angiosperm. International Journal of Current Microbiology and Applied Sciences 3(5): 702-711.

Qiu, H. \& Gilbert, M.G. 2003. Loranthaceae. Flora of China 5: 220-239.

Rabeta, M.S. \& Lin, S.P. 2015. Effects of different drying methods on the antioxidant activities of leaves and berries of Cayratia trifolia. Sains Malaysiana 44(2): 275-280.

Rodriguez, K., Ah-Hen, K.S., Vega-Galvez, A., Vasquez, V., Quispe-fuentes, I., Rojas, P. \& Lemus-Mondaca, R. 2016. Changes in bioactive components and antioxidant capacity of Maqui, Aristotelia chilensis (Mol) Stuntz, berries during drying. Food Science and Technology 65: 537-542.

Roshanak, S., Rahimmalek, M. \& Goli, S.A.H. 2015. Evaluation of seven different drying treatments in respect to total flavonoid, phenolic, vitamin $\mathrm{C}$ content, chlorophyll, antioxidant activity and color of green tea (Camellia sinensis or C. assamica) leaves. Journal of Food Science and Technology 53(1): 721729.

Salle, G. 1978. Origin and early growth of the sinkers of Viscum album L. Culture 26: 21-26.

Shabir, G., Anwar, F., Sultana, B., Khalid, Z.M., Afzal, M., Khan, Q.M. \& Ashrafuzzaman, M. 2011. Antioxidant and antimicrobial attributes and phenolics of different solvent extracts from leaves, flowers and bark of Gold Mohar (Delonix regia (Bojer ex Hook.) Raf.). Molecules 16(8): 7302-7319.

Shams, K.A., Abdel-Azim, N.S., Saleh, I.A., Hegazy, M.E.F., ElMissiry, M.M. \& Hammouda, F.M. 2015. Review Article Green technology: Economically and environmentally innovative methods for extraction of medicinal \& aromatic plants (MAP) in Egypt. Journal of Chemical and Pharmaceutical Research 7(5): 1050-1074

Siddhuraju, P. \& Becker, K. 2003. Antioxidant properties of various solvent extracts of total phenolic constituents from three different agroclimatic origins of Drumstick tree (Moringa oleifera Lam.) leaves. Journal of Agricultural and Food Chemistry 51(8): 2144-2155.

Stankovi,M.S. 2011. Total phenolic content, flavonoid concentration and antioxidant activity of Marrubium peregrinum $\mathrm{L}$. extracts. Kragujevac J. Sci. 33(12): 63-72.

Sultana, B., Anwar, F. \& Ashraf, M. 2009. Effect of extraction solvent/technique on the antioxidant activity of selected medicinal plant extracts. Molecules 14(6): 2167-2180.
Tan, E.S., Abdullah, A. \& Maskat, M.Y. 2013. Effect of drying methods on total antioxidant capacity of bitter gourd (Momordica charantia) fruit. AIP Conference Proceedings 1571(2013): 710-716.

Thaipong, K., Boonprakob, U., Crosby, K., Cisneros-Zevallos, L. \& Hawkins Byrne, D. 2006. Comparison of ABTS, DPPH, FRAP, and ORAC assays for estimating antioxidant activity from guava fruit extracts. Journal of Food Composition and Analysis 19: 669-675.

Thoo, Y.Y., Ho, S.K., Liang, J.Y., Ho, C.W. \& Tan, C.P. 2010. Effects of binary solvent extraction system, extraction time and extraction temperature on phenolic antioxidants and antioxidant capacity from mengkudu (Morinda citrifolia). Food Chemistry 120(1): 290-295.

Townsend, N., Nichols, M., Scarborough, P. \& Rayner, M. 2015. Cardiovascular disease in Europe - epidemiological update 2015. European Heart Journal 36(40): 2696-2705.

Turner, I.M. 1995. A Catalogue of the Vascular Plants of Malaya. Singapore: Singapore Botanic Gardens.

Werner, R. 2002. Medicines in Malay Villages. Kuala Lumpur: University of Malaya Press.

Yakob, H.K., Sulaiman, S.F., Uyub, A.M. \& Sciences, B. 2012. Antioxidant and antibacterial activity of Ludwigia octovalvis on Escherichia coli $\mathrm{O} 157$ : $\mathrm{H} 7$ and some pathogenic bacteria. World Applied Sciences Journal 16(1): 22-29.

Yi, W. \& Wetzstein, H.Y. 2011. Effects of drying and extraction conditions on the biochemical activity of selected herbs. HortScience 46(1): 70-73.

Zainol, M.M., Abdul-Hamid, A., Bakar, F.A. \& Dek, S.P. 2009. Effect of different drying methods on the degradation of selected flavonoids in Centella asiatica. International Food Research Journal 16: 531-537.

Zhang, Z., Lv, G., Pan, H., Wu, Y. \& Fan, L. 2009. Effects of different drying methods and extraction condition on antioxidant properties of Shiitake (Lentinus edodes). Food Science and Technology Research 15(5): 547-552.

Zhou, C., Li, X., Sun, C., Xu, C. \& Chen, K. 2011. Effects of drying methods on the bioactive components in loquat (Eriobotrya japonica Lindl.) flowers. Journal of Medicinal Plants 5(14): 3037-3041.

Zhou, K. \& Yu, L. 2004. Effects of extraction solvent on wheat bran antioxidant activity estimation. Swiss Society of Food Science and Technology 37(2): 717-721.

Vanielie Terrence Justine, Muskhazli Mustafa,

Sulaiman S. Kankara \& Rusea Go*

Department of Biology, Faculty of Science

Universiti Putra Malaysia

43400 UPM, Serdang, Selangor Darul Ehsan

Malaysia

Sulaiman S. Kankara

Department of Biology

Faculty of Natural and Applied Sciences

Umaru Musa Yar'adua

University P.M.B. 2218 Katsina, Katsina State

Nigeria

*Corresponding author; email: rusea@upm.edu.my

Received: 15 June 2017

Accepted: 18 April 2019 